\title{
Making up her mind: consent, pregnancy and mental handicap
}

\author{
Roger Higgs Editor
}

The following case was presented by a trainee general practitioner, working in inner London, to her release course for discussion. It is told, as it was presented, in the immediate aftermath of the events described. The names and some of the details have been altered.

Mary, a seventeen-year-old mentally handicapped girl, came to see Dr Davidson, a fellow trainee in the practice, complaining of a sore throat. As she was leaving she mentioned that she was pregnant and had attended the antenatal booking clinic of a London hospital outside our area. She had little idea of how far the pregnancy had progressed. Dr Davidson saw from her records that she had been registered with the practice since birth and had not been seen for several years. He decided to ask her to come back in a few days time for a full antenatal check-up. Meanwhile, he would try to find out more about her and her family. He discussed the consultation and his concerns about Mary with his trainer, Dr Daniel, and with Susan, one of the health visitors in the practice. Susan went to see Mary and the next day was able to give the following account to the weekly practice meeting of partners, trainees, nurses, health visitors and practice manager.

Mary's mother, Rose, was herself mentally subnormal; the aetiology was unknown. She had previously lived locally for many years and was well known to the senior partner in the practice, Dr Barnes. However, she was currently living in a hostel in the East End of London and had had little contact with Mary over the previous year. Mary had attended a school for the educationally subnormal where her IQ had been assessed as around 45. The aetiology of her handicap was also unknown. Since leaving the special school at the age of 16 , she had stopped living with her mother and had gone to stay on a boat on the Thames in London with a man called Peter. He had realised she had become pregnant when she missed two periods and had taken her to the local hospital where she had been seen by an obstetrician and a social worker in the antenatal clinic. As far as Susan knew, termination of pregnancy had not been discussed at the time. Shortly afterwards, Mary had left Peter and the boat and had come back to the practice area to stay with Ron and Ann. They were a couple in their sixties, also registered with and well known to the practice. Ron was the halfbrother of Mary's mother's consort and he and Ann had known Mary since infancy. Although she was quite capable of walking, Ann had adopted the role of an invalid and spent much of her time being pushed around in a wheelchair. Ron worked in the local market. Ann's own child had been taken into care as a toddler as she had been unable to look after him; thus the couple had no children of their own. They lived in some of the worst accommodation in the area, a tiny squalid prefab, which should have been pulled down years ago. The place was filthy and already overcrowded with Mary there. Mary had told Susan that she had left the boat because she did not like the people there and it was cold and damp. Ron and Ann alleged that Peter had been physically violent towards her. The conversation had been difficult but Mary had said twice, in Ron and Ann's presence, that she did not want to have a baby.

Susan asked everyone at the practice meeting what they thought should be done. Should the question of termination be pursued? What help could be offered if Mary decided to continue with the pregnancy? Here was an unsupported, mentally handicapped girl, who had become pregnant unwittingly, staying with an elderly couple in appalling housing conditions. Under those circumstances it seemed impossible that Mary would be able to look after her baby and it was likely that it would be taken into care. The feeling of the meeting was that the trauma of having a termination was likely to be less painful and damaging to Mary than the seemingly inevitable separation from her child after it had been born. We agreed that Susan should ask Mary to come to the surgery to talk to one of the doctors about having a termination, which should be arranged if possible.

Given this stark and bleak picture of Mary's life, I too felt that termination would be in her best interest, but I felt uneasy. To what extent were we prepared to take this matter into our own hands as doctors and make a decision which would profoundly affect Mary's life? Could she make an informed decision herself? What did Mary want? Would we be able to find out? Couldn't her circumstances be changed so that she could be given more care and support? Was it 'inevitable' that she would be separated from her child? Was there no environment where Mary and her baby could be helped to live together? Was she another 
casualty of overstretched resources and underprovision for the needs of the mentally handicapped?.

By chance, I saw Mary myself two days later. She had not turned up for her appointment so Susan had gone to fetch her. We saw her together.

A slightly odd-looking young girl came into the room looking rather apprehensive. She was keen to please in a childish way, and gave us smiles and grins as she chatted about her cats and her friends Ron and Ann. As we tried to broach the subject of her pregnancy she changed, her expression became vacant, she hung her head and was silent. She gazed around the room and finally broke the silence by telling us that she would be going to the pictures that afternoon. It was apparent that she barely understood what being pregnant meant and had little notion of what the demands of a small infant would be. She would not talk about it at all, nor did she express any feelings. Susan reminded her that she had said she did not want to have the baby; there was no reply. She certainly showed no understanding of what termination would involve and probably did not know what it meant. And yet, although she could not communicate anything in words, when we talked to her about it her face and posture looked vacant and then sad and perplexed. Was it completely beyond the bounds of any real understanding or did she have some basic, perhaps biologically determined, feelings about this fetus?

In talking to Mary, I began to realise how severely handicapped she was. I felt more unhappy. Would both termination or separation from her child have a profoundly devastating effect on her if she did have some limited way of understanding what it all meant? Might those simple feelings be terribly vulnerable? She had so little in many ways in the first place.

She identified Dr Barnes, who had known her mother, as being 'her doctor' and it seemed appropriate, if he agreed, that he should talk to her and be the doctor to recommend a termination. He was an experienced and gentle doctor who had understood many different sorts of people and helped them with their problems. Would he be able to communicate with Mary? Would he succeed where Susan and I had failed? Who could? Her mother was in the East End and apparently not involved, although Mary said her mother had told her to keep the baby. Could we get help from her previous teachers or people who were skilled at communicating with handicapped children? Her school had closed down and the teachers had dispersed. I felt it would not be appropriate to bring them into this matter.

Dr Barnes agreed to see Mary a few days later. Meanwhile, as it was important to have an accurate assessment of how far the pregnancy had progressed, an ultrasound scan was arranged. Susan took Mary home. Ron and Ann were out. What did they think? It was going to be important to find out.

Mary came to see Dr Barnes and I was present at the interview. It was much the same as when Susan and I had seen her a few days before. She was pleased to see him and happy to chat but silent on the subject of the pregnancy or what should be done. He told her he felt it would be best for her to have a termination and that he would write a letter and arrange for her to go to the hospital. He signed the green form. As well as the social and psychological implications of Mary's having this baby, there was the unanswerable question of how likely it was that this child too would be mentally retarded. The cause of Mary's and her mother's mental retardation was unexplained. Was this a hereditary pattern?

The scan showed Mary was fifteen weeks pregnant. I telephoned the senior registrar at the local hospital and explained the situation to him. I said the doctors in the practice felt a termination would be in Mary's interest. Would he be prepared to perform an extraamniotic abortion? The senior registrar was prepared to consider her but sounded uneasy. Both his consultants were away and he would want to discuss it with another consultant and the medical social work department. It was a decision he would not wish to make on his own and ultimately it was the consultant's responsibility. The question of consent was difficult. Mary was over 16 and her mother's permission was not necessary, but could she really be said to be capable of giving informed consent? If she could not, was this a matter just for the doctors, and how much should social workers and the law be involved?

After seeing Dr Barnes I took Mary home. We went in to find Ann surrounded by innumerable cats and considerable filth and squalor. I told Ann what Dr Barnes had recommended and that Mary had an appointment to be seen by the gynaecologists. She appeared uninterested and would not enter into a discussion about it. Mary danced around, apparently oblivious, while Ann showed me the chidren's story books they had bought to teach Mary to read and write. I left saying that Mary should come to the surgery the following Thursday, when I would take her for her appointment at the hospital.

Thursday came. Mary didn't turn up. I went to the house and there was no reply. Had they forgotten, or were they deliberately out? I came back to the surgery to talk to Susan. She knew they often went to the post office on Thursdays and to the market. It was getting late; should I go and look for them? Was that going too far? I set off again in the rain to search the market and the shops. What were they going to say when I did find them, I wondered?

Some of the purely practical realities were becoming clear to me and they were going to be pretty unpleasant for Mary. It would not be a quick general anaesthetic and a scrape, but drips and catheters, vaginal examinations, needles and pain. She would be lying in a hospital bed surrounded by unfamiliar faces, not understanding what was being done to her. She would probably be terrified. I would be sure to ask the gynaecologist to sedate her heavily throughout it all but was that right or even possible?

Mary was not to be found in the market nor had she turned up at the surgery. As a last resort, I went back to the prefab. As I drove up I saw Mary, Ron and Ann in 
the street outside the house. Ann recognised my car and as I pulled up was brandishing her stick, threatening to break the car windscreen if I didn't go away, swearing that I was up to no good and trying to take away the baby which Mary wanted. I had half expected this, but was still unprepared and would have preferred the scene not to be taking place in the middle of the street. I got out of the car and after quite a bit of shouting Ann calmed down. Ron spoke simply and quietly and told me that he thought that Mary wanted to keep the baby. He said that after her interview with $\mathrm{Dr}$ Barnes she had come home and cried for several hours. She would not talk and refused to eat her tea. He felt she had been deeply upset. What exactly had Mary been upset about? What had Ron and Ann said to her? Had they told her that she should have the baby and that we were ogrish doctors? Or did Ron have some understanding of this girl which I did not have? He was saying that he had known Mary from when she was a little girl, he cared about her and wanted to help her. He and Ann had very little, they were poor, their house tiny and squalid, but she could stay with them if she wished. They had sorted out her social security payments and would teach her how to use money. They had bought her a new coat, given her a front door key and were trying to teach her to read and write. 'Yes' I said, 'but Ron, isn't that enough for you to do? Mary needs a lot of loving, nurturing and helping, herself; might it not be beyond your resources to look after her and a baby as well?' He persisted; he and Ann knew how to look after children, they would teach and help Mary to feed, change and bath the baby. 'But babies aren't babies forever, they grow into toddlers, children, teenagers. Could you give Mary and her child that support for fifteen, twenty years?

'Look', he said, 'when you live like us you don't have big plans like that for the next fifteen years, not a year from now, not even a few months. We live from day to day and we manage. If you want to do anything useful you could get us rehoused, that would help the baby as well.'

I suddenly felt very humbled. How much did I care about Mary and her baby - in my professional role as a doctor, or as another individual standing next to this man in the street? Could I separate those two roles? As a doctor I had particular skills and certain power and authority; as an individual I wasn't offering to have Mary stay with me. I found Ron's words quite disturbing even though I was convinced that his household would be quite unsuitable for a small child who would need more security than the day-to-day commitment Ron was offering. I envisaged the anger and resentment Ron and Ann would feel if the baby were born and taken into care. Not only would Mary be deemed to be incapable of looking after the child but so would they, in a far more direct way than if she had a termination. I felt angry too about a society that had established structures to care for Mary as a child, recognise her special needs, provide special education just up to the time she was 16, and then left her entirely to her own devices. She was still only a child and it needed a crisis like this to provoke professionals into 'caring' about Mary again.

It was clear that Mary would not be going to the hospital that day. Ron and Ann, with no legal rights, were in control of the situation. I had no legal status and the social services department was likely to be unwilling to take legal responsibility to procure a termination. There was nothing to be done and I left with Ann's angry words ringing in my ears. 'If you come back here again, or any of your lot, interfering with this girl, I'll make sure it's all over the front of the News of the World.' What would the 'general public's' opinion of the situation be?

I felt wretched; not so much because I had been thwarted in my attempt to take Mary to the hospital but because the whole situation looked depressing. I went back to the surgery and talked through my confused thoughts and feelings with Susan. She was very supportive and helped me to disentangle them. It was important to have a colleague with whom I could share my feelings. In the afternoon I was able to discuss Mary with the other trainees in the half-day release course. How could we learn to communicate better with people like her? How much should we take responsibility for making crucial decisions that affect other people? We felt angry about the lack of provision of reasonable resources within our welfare state. I was relieved to have a safe forum where I could talk about how I had felt and how I could deal with those feelngs. It was helpful to be able to discuss this away from the practice.

As Mary was going to continue with her pregnancy, we arranged for her to be booked at the local hospital and to attend the antenatal clinic. A case conference was held with the area social workers to inform them of the situation and discuss our worries about Mary. We hoped that some advanced planning would make the situation easier and that she could be offered some practical help, particularly with regard to accommodation. However, the social work department was unable to allocate a social worker at the time because of lack of resources and said it would be two or three months before a new worker joined their team. Nothing concrete could be offered at the time. Clearly, it was going to need another crisis before the professionals were provoked into 'caring' again.

A week later, Mary came to the surgery with a sprained wrist. She could not account for how it had happened. Ann alleged that Peter had come round to the prefab and beaten Mary up. Within a few days she was back again. 'I'm getting married in September, doctor' she said with a big grin. I was surprised because I knew Peter was already married. A few moments later she was in tears saying that Peter wanted to take her away to the boat. She didn't want to go and wanted to stay with Ron and Ann.

Three weeks later, Peter called at the reception desk. Mary had left our area to live on the boat with him again. There was no address, she was not registered with a doctor, presumably social services did not know about her either. Peter asked us to get her antenatal 
notes transferred back to the hospital where she had originally booked. They were planning to take the boat to Spain for the summer holidays - about the time Mary's baby was due!

Who, if anybody, cares about Mary now?

\section{Postscript}

Three months later, Ron and Ann came to see me at the surgery. Cautiously, I asked them what had happened to Mary. The answer seemed to reveal once again the fragility of Mary's relationship with everyone. 'We don't know and we don't care', they said. 'We don't want to see her again.'

'Why's that?', I asked.

'She played a dirty trick on us, she did. She left owing us one week's rent.'

\section{Commentary 1}

\section{David Metcalfe Department of General Practice, University of Manchester and General Practitioner}

The central issue in this case is whether the health professionals should 'play God' in the absence of what might be called competent decision-makers among the lay people involved. Mary is educationally subnormal and nobody appears to have the rare skills needed to ascertain her feelings about her pregnancy or even her level of understanding of it. Peter would appear to have forfeited any say in the matter when the relationship broke up (but we don't know how he felt) and her mother, no longer her legal guardian, is not readily available. Ron and Ann appear to be unable to maintain a 'suitable' household for Mary and her child. There is, prima facie, a high risk that the child will, itself, be mentally handicapped. The scene is set for the health professionals to do what they think is best and with our value system that looks like a termination.

The trouble is that the decision has to be made now, not when we know the mental status of the baby, the success of an attempt to get Ron and Ann rehoused, Peter's preparedness to take on the responsibilities as the father, and so on and so forth. Good outcomes in all these matters are devoutly to be hoped for but can only be marginally influenced by the health team after they have made their decision.

The eugenic solution is termination: I have a rooted feeling that most eugenic solutions are unethical!

The central issue is one of informed consent. Mary has conceived by the usual process and is pregnant: a normal physiological process. Anything that is done to her to alter that state and its natural history therefore must have her informed consent. I can see no way in which this could be obtained because one could not be sure as to whether what she said or signified was consent nor the extent to which she had sufficient understanding of the issues to be said to be informed. (I think the trainee's concern for the distress of the termination procedure here is a red herring: much the same will happen when she is in labour.) In the absence of such informed consent termination should not be undertaken and contingency plans should be mounted to deal with the baby in such a way as to protect its rights when it arrives.

Given this central point, Ron and Ann's attitudes throughout become secondary. Neither overcrowding, squalor, nor living from hand-to-mouth, and day-today, are totally inimical to love, warmth, protection and provision. Whole generations have grown up in such circumstances and even after thirty years of the welfare state some still do and, because of the resilience of the human animal, survive as people. Mary's baby's upbringing could well offend middle-class value systems but could hardly be said to be an indication for killing it. Equally, Ron and Ann's eventual comment on Mary reflects the realities of their hand-to-mouth existence and quite possibly the pain of their rejection rather than their basic unsuitability as surrogate grandparents. Anyhow, I am not at all sure which of the four criteria for termination could be applied in this case!

On one side is the eugenic solution: on the other only faint hopes. The faint hope that childbirth and carefully supervised child-rearing might give some meaning to Mary's life; the faint hope that it would bring forth in Peter protective feelings toward both Mary and the baby; a stronger hope because there is no real evidence against it, that the baby would be mentally normal; the hope, whose strength would depend on the social services department concerned, that Ron and Ann's behaviour represented pragmatic protectiveness rather than avarice and that it might be rewarded by the provision of civilised housing. How few, and how faint, do hopes have to be before they can be ethically dismissed?

Denouéments may justify or call in question the effectiveness of management decisions but surely not their ethics? Peter and Mary will take risks in much the same way that Ron and Ann will not plan. The risktaking and the non-planning may be improvident, expensive for society, and disastrous for themselves, but that's what autonomy is about.

\section{Commentary 2}

\section{John Harris Department of Education, University of Manchester}

Anything said by way of commentary on a case like this must presuppose an answer to two very fundamental questions. They are: What is it to be fit to be a parent and what are the conditions required for minimally adequate child-rearing? As a society we take great care to examine the adequacy of adoptive parents but usually no care at all to examine the adequacy of 'natural' parents. The same is true of the conditions surrounding natural and adoptive child-rearing. There is clearly 
an inconsistency here which might be resolved in one of two ways. We might decide that if it is right to decline to surrender adoptive children into the care of people whom we are not satisfied are fit to look after them we are, for the same reasons and to the same extent, obliged to scrutinise natural parents. Alternatively we might conclude that if it is unnacceptable to vet natural parents we should give adoptive parents the same benefit of the same doubts, at least until the parents in either case demonstrate palpably that they are unfit.

However, in the absence of a general and fair scheme for scrutinising all parents and without a clear conception of what constitutes fitness, it is both invidious and disturbing when chance leads to a particular parent being effectively declared unfit in the absence of, and in advance of, any palpable evidence. If low IQ or inadequate housing or even the presence of elderly and perhaps unsupportive people were disqualifying conditions for parenthood the world would quickly become depopulated. This might well be a good thing, but it is far from clear that such a policy should be initiated by general practitioners and even health visitors on their own say-so. On the evidence presented by the very conscientious and caring author of Mary's case this is not far from what was contemplated and indeed almost happened.

The author reports that the practice meeting agreed to arrange a termination if possible on the basis of their judgment that 'here was an unsupported, mentally handicapped, girl, who had become pregnant unwittingly, staying with an elderly couple in appalling housing conditions. Under those circumstances it seemed impossible that Mary would be able to look after her baby and it was likely that it would be taken into care'. The author further reports that 'the feeling of the meeting was that the trauma of having a termination was likely to be less painful and damaging to Mary than the seemingly inevitable separation from her child after it had been born'.

The grounds cited in this passage as supporting the decision of the practice meeting are interesting because they are either erroneous or inadequate or both. The only factor that could justify the termination of Mary's pregnancy without her consent is largely unexplored and even unknown. This is, of course, the extent of Mary's handicap and the question of whether or not she understands, and so is capable of consenting to, any of the things that are proposed on her behalf.

Firstly we should note that the decision arrived at by the practice meeting was, so to speak, the operative one. For although Mary was later seen by doctor Barnes who 'signed the green form', he clearly based his view that it 'would be best for her to have a termination' on the 'facts' either available to or more likely provided by the practice meeting or those who attended it. From then on all went like clockwork except for Mary's absenting herself at the crucial moment. It's also worth noting for the record that the practice meeting's decision that Mary should not keep her child if she did have it was also likely to be influential, since the practice held a case conference 'with the area social workers to inform them of the situation and discuss our worries about Mary'.

Since the practice meeting's decision was so important one might have expected Mary to be present herself at this meeting or at least represented at it. So far as we can tell the extent of Mary's handicap was not seriously assessed. An IQ of around 45 is a fairly borderline figure, from which very little can be deduced about Mary's abilities; particularly because we have no information about the tests used or the skill of those administering them. We do not even know when she was tested. Was it at the beginning of her school career or at the end? The fact that Mary attended a school for the educationally subnormal indicates that she must have at some time made good progress. However, the author of the case study remained rightly unsure about the extent of Mary's understanding and yet, despite the absence of consent let alone informed consent, Dr Barnes felt able to arrange a termination. However, without adequate reasons for concluding that Mary was incapable of choosing for herself or bringing up a child, the other considerations must have been decisive; but when looked at they can be seen to be either erroneous or inadequate.

Firstly, 'here was an unsupported . . . girl'. She was not. Such evidence as the case history presents indicates that Ron and Ann were signally supportive. 'They had sorted out her social security payments and would teach her how to use money. They had bought her a new coat, given her a front door key and were trying to teach her to read and write'. True this 'evidence' was not available to the practice meeting but decisions were taken and opinions formed without anyone taking the trouble to substantiate the grounds for such opinions and decisions.

\section{Red herring}

Mary's becoming pregnant 'unwittingly' is clearly a red herring since this is also true of many (perhaps most?) normal pregnancies. The fact that she is living with an elderly couple in appalling housing conditions will only be relevant factors in either recommending termination or taking the child into care, if it is judged that Mary is herself incapable of looking after it. It must be emphasised that the extent of Mary's handicap is the crucial, indeed the only significant, issue in this case and the other grounds for the practice meeting's decision would not be regarded as grounds at all were it not for Mary's handicap. Indeed, were she not mentally handicapped she might have found it more than a little difficult to secure a termination in circumstances like these even if she wanted one. 
Then, there is the question raised by the author of whether or not the mental retardation is likely to be hereditary in this case. Again, if the question of whether or not to risk having a mentally retarded child is a question for anyone it is a question for the parents or in this case the mother. Mary would have to be asked whether, if the child was likely to be very like herself, she would think it better that the child should not exist at all!

\section{Conclusion}

To conclude: The decision to terminate Mary's pregnancy should not be taken without Mary's informed consent and should not be taken unless it is clear that she is so handicapped as to be incapable of giving such consent: and even then, only if the other more fundamental questions with which we began have clear answers or a clear view has emerged as to what might be adequate grounds for a general policy of denying to the handicapped the opportunity to reproduce and be parents. Such a discussion is beyond the scope of a brief commentary. In the present case it remains unclear as to whether Mary is capable of giving the required consent and her reported remarks about not wanting a child could not amount to consent to abortion for it is one thing to wish not to be pregnant or to have children and quite another to want an abortion.

There is, of course, an alternative to the frame of reference of this case study. This the author rightly and repeatedly indicates would involve much better provision for the handicapped so that they might be properly supported, so that they might have an equal chance of enjoying some of the basics of life like procreation and child-rearing which the rest of us take for granted.

Finally, would it have been better for Mary had she had the abortion? Probably it would. But it does not, of course, follow from this that anyone had the right to arrange this without her consent, and certainly not without at least a much fuller investigation of the extent of her handicap and without her being adequately represented where any vital decisions were taken.

\section{Postscript}

The postscript to the case study adds nothing to our knowledge of Mary's situation although it might seem to indicate that Ron and Ann did not really care for Mary. It might indicate this but it might equally be the reaction of people who loved her very much and were deeply hurt by her sudden departure. The tendency to draw quick and consequential conclusions was much in evidence in this case and we should be wary. Without a proper investigation or deep knowledge of the circumstances we do not have the right to draw conclusions still less act on them in ways that affect Mary so fundamentally.

\section{Commentary 3}

Gillian Lockwood and Michael Lockwood fohn Radcliffe Hospital and Department for External Studies, Oxford University, respectively

Most people would agree that autonomy is a value, that it is an intrinsically good thing that people be allowed to decide for themselves what happens in matters that affect their lives. That belief forms a large part of the rationale for the increasingly fashionable concept of informed consent. In its application, however, the concept of personal autonomy is both self-limiting and limited by other considerations. It is self-limiting in the sense that allowing unlimited autonomy to one is ipso facto a denial of autonomy to others: the familiar precept, cited by Isaiah Berlin in his Two Concepts of Liberty, that freedom for the pike is death for the minnows. One person may have a legitimate interest in some matter but so may another; it is then a logical impossibility to allow both the whole say in the matter. Autonomy is also limited by other considerations, in that it is not the only thing we value. Human welfare, for example, is equally a value. Where, in deciding for themselves, people are in serious danger of doing themselves harm, the values of autonomy and welfare are in conflict with each other; and if the consequent loss of liberty is small by comparison to the gain in welfare, we may think it legitimate that autonomy be overridden. A good example is recent car seatbelt legislation.

There are, broadly speaking, four sorts of reason for which we may think it right for a decision to be taken out of the hands of the person most immediately affected:

(i) The person is simply not capable of deciding for himself or herself, at any rate in any meaningful sense; someone else then has to do the deciding.

(ii) The person is capable of making a decision, but the danger that the person will decide irresponsibly, or on the basis of inadequate knowledge or understanding, thereby placing his or her own welfare at risk, is considered too great. (It is on these grounds, mainly, that the medically unqualified are not, in this country, allowed unlimited freedom to prescribe for themselves.)

(iii) Others, in virtue of the relationship in which they stand to the person, have a legitimate interest in that person's welfare which in the circumstances entitles them to decide on behalf of that person.

(iv) Others, in virtue of the relationship in which they stand to the person, have legitimate interests relating to their own welfare or that of third parties, which again may override that of the person most immediately affected.

Considerations of all four kinds seem to arise in the case of Mary. Significantly, they all arise also in the case of children, particularly vis-à-vis their parents. There are 
all kinds of matters on which very young children are incapable of making a decision, let alone an informed decision, because they simply lack the relevant concepts. Here someone else has to make the decision on the child's behalf; and this will generally be the parents. On other matters, a child can make a decision, even an informed decision, but is all too likely to choose irresponsibly, say by discounting (as an adult would think, irrationally) the likely long-term consequences. Here it is considered desirable that the decision be made by some 'responsible' adult or adults, and once again, this will normally be the parents. But finally, parents, because they are the parents - with all that this generally entails in terms of emotional attachment and time, money and energy invested would normally be thought to have a legitimate interest, a stake in their children's welfare, which once again makes it intrinsicially right that they should have a substantial say in matters that centrally concern their children.

Let us be a little more precise. Consideration (i) makes it sometimes necessary, consideration (ii) makes it very often desirable, that some person or persons other than the child has the final say on matters that most immediately and centrally affect the child. The special relationship in which normal parents stand to their children then makes it appropriate that it be they who do the final deciding in matters where considerations (i) and (ii) apply. But also, in virtue of this relationship, extra reasons, (iii) and (iv), which involve their own autonomy, are brought into play to weigh against the autonomy of the child. This is the moral basis of the child's relative lack of autonomy, as compared to a normal adult, and the corresponding moral authority that the normal parent has over his or her children.

What makes the case of Mary so perplexing, both practically and philosophically, is just this. Considerations (i) and (ii) are clearly going to apply, in her case, to many of the decisions that a normal adult would have to make (though it is left unresolved, in the case history, whether in regard to the decision whether or not to have a termination, Mary is incapable of making a decision at all, or incapable merely of making a responsible, informed decision). Mary is intellectually and emotionally a child, even if she has a woman's body, and sadly is fated never to acquire the mind of an adult. But on the other hand, there is nobody, in her case, who can be regarded, either legally or morally, as having parental standing.

The sad and complex history of Mary can be seen largely as an ultimately futile series of attempts by the professionals to break out of the impasse by denying, in one way or another, that the situation is as we have just described it. First, there is the attempt on the part of Susan, the health visitor, to get some sort of meaningful decision out of Mary herself, to treat her as an adult. Mary says she does not want to have her baby. But doubt is rapidly thrown on the genuineness of this 'decision', both by her silence and her apparent incomprehension of what is involved, when interviewed by the trainee and later by Dr Barnes, and by Mary's reported distress following the latter interview. Following upon that failure, the professionals proceed - if only by default - on the basis that Ron and Ann should be regarded as de facto parents and that their assessment of what is best for Mary be allowed to prevail. This in spite of the squalor of their home and Ann's own personal inadequacy and inability to care for her own child. But this too proves a failure. However highly motivated Ron and Ann were in their desire to keep and support Mary and the baby, the postscript reveals how fragile was this attachment and determination, and how mistaken it would have been, in retrospect, to include their opinions and desires in the calculation of where Mary's best interests lay.

The story of Mary shows all too clearly that where the professionals hang back in providing direction and counselling, the vacuum is liable to be filled by incompetent if well-meaning amateurs; and that it is their wishes and opinions that will then determine what happens. In the end, it is the boyfriend, Peter, who takes control of the situation. Whether he can be said to have Mary's best interests at heart seems doubtful in the extreme; certainly he gives no indication of being prepared to take responsibility for her child, or to take his relationship with Mary any more seriously than he did his own marriage. We end, seemingly, in the worst of all possible worlds. The State, that has effectively relinquished responsibility, is liable to pay for this, in due course, by having to assume the burden of an unwanted, very likely mentally subnormal child. And if it proves to be a girl, the whole sorry cycle seems in danger of repeating itself.

At other times and in other places, the problem represented by Mary might not have presented itself in this form. In Britain, in the recent past, Mary would most likely have been confined in an institution. In certain states in America, she would be quite likely to have been compulsorily sterilised. But current opinion in Britain is opposed to such measures, as is reflected in the current state of the law. There was a recent test case in this country in which a mother with a mentally subnormal teenage daughter for whom the pill was considered unsuitable was refused permission to have her daughter sterilised. The change in attitude towards the mentally subnormal has, of course, gone hand in hand with a trend towards allowing children greater freedom. In so far as this change in attitude embodies a recognition that autonomy is something to be valued, even in the child, the senile, the mentally handicapped and the mentally ill, it is clearly something to be welcomed. But such commendably libertarian principles are all too often used, by those in authority, to justify a policy of non-interference, noninvolvement even, in people's lives, that in practice can amount to appalling neglect.

It is easy, of course, to blame the situation, as the 
author of the case history seems inclined to, on the lack of resources within the welfare state. There are some excellent hostels offering support and a noninstitutional, family-like environment for people like Mary, while enabling them to live and perhaps even find work within the community. It is arguable, certainly, that if more of these were available, predicaments such as the one Mary found herself in would arise less frequently and be more easily resolved, in a satisfactory manner, when they did arise. But the lack of such care facilities seems to us only part of the difficulty. Surely, the problem stems equally from the absence of clear legal guidelines and the unwillingness of the authorities to take effective steps. In part, no doubt, it is precisely the absence of guidelines that deters the authorities from acting; but, as we suggested just now, an excessively laissez faire attitude also seems partly to blame for this.

Thus, the author of the case history raises, in passing, the possibility of the local authority attempting to procure a termination. Since Mary was still - just - a minor, this could perhaps have been accomplished by having her made a ward of court. It should be emphasised, though, that, morally speaking, the chronological, as opposed to mental, age of Mary is an irrelevance; and it is surely an anomaly in the law that, if Mary were a few months older, even this move would be unavailable. But, at any event, we are told that 'the social services department was likely to be unwilling to take legal responsibility to procure a termination'.

It is, however, an interesting and important question whether, supposing that the authorities had been willing and able to procure a termination for Mary, it would have been right for them to do so. Right, that is, assuming that terminating a pregnancy, under these circumstances, is itself to be considered morally permissible: we take it that the morality of abortion is not the main point at issue in this case history.

We think that, all things considered, it would have been right. By this we do not mean that a termination should have been forced upon Mary, even if she expressed a clear and unambiguous resolve to have her baby. No one, we take it, is suggesting that Mary be carried kicking and screaming to the operating table. But that does not apear to be the situation. Rather, Mary seems not to have any effective will of her own here. In her confused, frightened and bewildered state of mind, she appears willing to bow to the pressures and persuasions of the moment. There is every reason to think that, away from her supposed 'friends', Mary would passively go along with whatever the professionals proposed. And, however great the trauma involved in a termination, it could hardly be greater, surely, than that of giving birth. After a termination, some form of contraception appropriate to Mary's situation might then be devised.

But what moral right, it may be asked, do the authorities have to impose their will in this situation? (Ann's threat may be no idle one: one can certainly picture the newspapers indignantly asking this very question.) The author of this case history clearly makes an important philosophical point when she suggests that, in failing to provide adequate care for Mary, they have perhaps forfeited whatever right they might otherwise have had to make decisions on her behalf. As the author points out, Ron and Ann are, after all, as it then seems, prepared to take responsibility for Mary, offer her a home and provide for her as best they can out of their pitifully meagre resources. What are the authorities offering?

This is hardly the place to get involved in the thorny problem of the proper limits or basis of political authority, save perhaps to remark that to believe in the welfare state at all is by implication to endorse a conception of government as having at least a quasipaternal role in relation to its citizens. The two key points seem to us to be these. First, whatever doubts one may have about the moral rights of the authorities in this case, if Mary is, as she seems to be, incapable of making a meaningful decision of her own, someone has to make it for her. And no one in the situation, not even as it turns out Ron and Ann, has a better right or is in a better position than the authorities to do this. Were the decision to have been made by the authorities, under the guidance of the doctors and health visitor, that would surely have been far preferable, morally, to the actual outcome, in which the decision is taken (or allowed to go by default) by Peter, who beats Mary, lies to her and, in spite of being the biological father, shows no real interest in Mary's baby or in Mary's own welfare.

The second point is that the State does have a legitimate interest in the matter of whether Mary has her baby if, as seems very probable, it is on the State that the burden of caring for the child is ultimately bound to fall. Consideration (iv), above, clearly has some force here. In this regard, the point about rights going along with responsibilities clearly works in the authorities' favour.

In conclusion, it seems that in their failure to act up to the limit of their full powers, the various professionals considered that it was easier, perhaps even more desirable, to let things happen and to deal with their consequences, than to act pre-emptively and prevent such occurrences. Such a stance may be easier to adopt and even to defend at a superficial level. But as a policy it is not only wasteful of scarce resources but also totally neglectful of welfare considerations. Normal adults generally do not need and do not want decisions made for them, even where the increase in welfare can be clearly demonstrated; their loss of autonomy cannot be compensated for that way. But the sad story of Mary demonstrates clearly that there is a sector of society for whom justice and kindness demand that such paternalism be exercised. 